I-Economic Vol. 4. No 2. Desember 2018

Maqashid Koperasi Syariah .... Nurhadi

\title{
MAQASHID KOPERASI SYARIAH
}

\section{Nurhadi}

Sekolah Tinggi Agama Islam (STAI) Al-Azhar Pekanbaru

alhadicentre@yahoo.co.id; alhadijurnal@gmail.com; hadiaksi71@gmail.com

\begin{abstract}
The Islamic finance industry in the frame of Islamic financial institutions in the economy of a country plays a very important role, one of which is to assist businesses in carrying out, expanding, and developing their business activities through financing, among which are cooperatives that provide financing to cooperative members. Maqashid Koperasi sharia is a community-based business or business activity. His own philosophy is selfreliance, starting from the self and then to the independence of the group (people). Or vice versa, group independence that encourages individual independence in it. The resources gathered from members are a way to achieve economic sovereignty, so cooperating is actually a long-term business strategy that secures the business interests of each member from unfair competition. Cooperating is building a fortress from efforts to destroy and colonize large investors and more established business owners. Maqashid Sharia cooperatives at the level of religion are concentrations of power in driving out forbidden forms of muamalah and misleading ideologies. Riba is the prima donna of the business world, its existence is a direct derivative of the capitalist notion that puts money above everything else. Only solidarity is able to withstand the onslaught of expansion of capitalist business ventures, the institutionalized solidarity called cooperatives. Maqashid syirkah Islamic cooperatives contain six maqashid, as follows: 1). A large amount of capital is collected, so that it can be used to carry out large jobs too; 2) Can expedite the macroeconomic rate; 3). The creation of broader and more adequate employment opportunities; 4). The feeling of brotherhood between fellow capital holders and other partners; 5). Thought to advance the company becomes more because it comes from many people too; 6). Union transactions can generally be terminated or canceled.
\end{abstract}

Keywords: Maqashid, Koperasi, Sharia.

Abstrak
Industri keuangan syariah dalam bingkai lembaga keuangan syariah dalam perekonomian suatu negara memegang peranan yang sangat penting, salah satunya membantu para pelaku usaha dalam menjalankan, memperluas, dan mengembangkan kegiatan usahanya melalui pemberian pembiayaan, diantranya adalah koperasi yang memberikan pembiayaan kepada para anggota koperasi. Maqashid Koperasi syariah adalah berjamaah dalam usaha atau kegiatan usaha yg berbasis komunitas. Filosofinya sendiri adalah kemandirian, mulai dari diri kemudian menjadi kemandirian kelompok (umat). Ataupun sebaliknya, kemandirian kelompok yang mendorong kemandirian individu didalamnya. Sumber daya yang terhimpun dari anggota adalah jalan bagi pencapaian kedaulatan ekonomi, sehingga berkoperasi sebetulnya adalah strategi usaha jangka panjang yang mengamankan kepentingan bisnis setiap anggota dari persaingan yang tidak sehat. Berkoperasi adalah membangun benteng dari upaya-upaya menghancurkan dan menjajah para pemodal besar dan pemilik usaha yang lebih mapan. Maqashid Koperasi syariah dalam 
I-Economic Vol. 4. No 2. Desember 2018

Maqashid Koperasi Syariah .... Nurhadi

tataran religi adalah pemusatan kekuatan dalam menghalau bentuk-bentuk muamalah yang terlarang dan ideologi yang menyesatkan. Riba itu primadona dunia usaha, keberadaannya adalah turunan langsung dari paham kapitalis yg mendudukkan uang diatas segalanya. Hanya solidaritas yg mampu menahan gempuran ekspansi usaha bisnis kapitalis, solidaritas yg melembaga itu namanya koperasi. Maqashid syirkah koperasi syariah mengandung enam maqashid, sebagai berikut : 1). Terkumpulnya modal dengan jumlah yang besar, sehingga dapat digunakan untuk mengadakan pekerjaan-pekerjaan besar pula; 2). Dapat memperlancar laju ekonomi makro; 3). Terciptanya lapangan pekerjaan yang lebih luas dan memadai; 4). Terjalinya rasa persaudaraan diantara sesama pemegang modal dan mitra kerja yang lain; 5). Pemikiran untuk memajukan perusahaan menjadi lebih banyak karena berasal dari banyak orang pula; 6). Transaksi perserikatan secara umum bisa berahir atau batal.

Kata kunci: Maqashid, Koperasi, Syariah.

\section{Pendahuluan}

Lembaga keuangan merupakan sebuah perantara dalam menghimpunan dalam dari masyarakat dan menyalurkannya kepada masyarakat. Lembaga keuangan terdiri dari lembaga keuangan bank dan bukan bank. Lembaga keuangan cukup berperan penting dalam perekonomian di Indonesia dan merupakan salah satu aspek yang penting dalam kehidupan manusia baik dalam bertransaksi, penyimpanan, layanan pembayaran maupun kebutuhan akan dana. ${ }^{1}$ Salah satu lembaga keuangan non bank dalam kontek lembaga keuangan mikro adalah koperasi. Fngsinya hampir sama dengan lembaga keuangan perbankan, yaitu jasa, investasi berupa kepemilikan kendaraan bermotor dan logam mulia, pembiayaan usaha serta kebutuhan akan dana. ${ }^{2}$

Penomena geliatnya ekonomi Islam di Indonesia dalam lima belas tahun terakhir ini, mengalami perkembangan signifikan baik dalam tataran teori dan praktik. Akselerasi pertumbuhan Lembaga Keuangan Syariah (LKS) terus mengalami kemajuan. Sebagai contoh, Bank Muamalat yang sudah berdiri sejak tahun 1992 dan bank syariah lainya. ${ }^{3}$ Kemudian diikuti dengan LKS lainnya, seperti Pegadaian Syariah, Asuransi Syariah, hotel Syariah, Reksadana Syariah, Koperasi Syariah dan lain sebagainya. ${ }^{4}$

Industri keuangan syariah dalam bingkai lembaga keuangan syariah dalam perekonomian suatu negara memegang peranan yang sangat penting, salah satunya membantu para pelaku usaha dalam menjalankan, memperluas, dan mengembangkan kegiatan usahanya

\footnotetext{
${ }^{1}$ Muftifiandi, Peran Pembiayaan Produk Ar-Rum Bagi Umkm pada PT. Pegadaian (Persero) Cabang Syariah Simpang Patal Palembang (Jurnal I-Finance Vol. 1. No. 1. Juli 2015), hlm. 93

2Julius R. Latumaerissa, Bank dan Lembaga Keuangan Lain, (Jakarta: Salemba Empat, 2013), hlm. 459

3Dinnul Alfian Akbar, Inflasi, Gross Domesctic Product (Gdp), Capital Adequacy Ratio (Car), dan Finance To Deposit Ratio (Fdr) Terhadap Non Performing Financing (Npf) Pada Bank Umum Syariah di Indonesia (Jurnal IEconomic Vol. 2. No.2 Desember 2016), hlm. 19

${ }^{4}$ Zainil Ghulam, Implementasi Maqashid Syariah dalam Koperasi Syariah (Jurnal Iqtishoduna Vol. 7 No. 1 April 2016), hlm. 92-94
} 
I-Economic Vol. 4. No 2. Desember 2018

Maqashid Koperasi Syariah .... Nurhadi

melalui pemberian pembiayaan. ${ }^{5}$ Di tengah kemajuan perkembangan ekonomi syariah di Indonesia, berbagai perbankan syariah berlomba-lomba melakukan kegiatan pemberian pembiayaan kepada para pelaku usaha mikro, kecil, dan menengah. Lembaga keuangan mikro seperti koperasi, terutama koperasi syariah tidak luput dalam memberikan pembiayaan melalui pemberian pembiayaan kepada para anggota koperasi. ${ }^{6}$

Koperasi sebagai wadah kemitraan, kerjasama, kekeluargaan, dan kebersamaan usaha yang sehat, baik dan halal adalah sesuatu yang sangat dipuji Islam berdasarkan firman Allah Swt dalam surah al-Maidah ayat 2 sebagai berikut:

Artinya: Hai orang-orang yang beriman, janganlah kamu melanggar syi'ar-syi'ar Allah, ${ }^{7}$ dan jangan melanggar kehormatan bulan-bulan haram, ${ }^{8}$ jangan (mengganggu) binatang-binatang had$y a,{ }^{9}$ dan binatang-binatang qalaa-id, ${ }^{10}$ dan jangan (pula) mengganggu orang-orang yang mengunjungi Baitullah sedang mereka mencari kurnia dan keredhaan dari Tuhannyal ${ }^{11}$ dan apabila kamu telah menyelesaikan ibadah haji, maka bolehlah berburu. dan janganlah sekalikali kebencian(ти) kepada sesuatu kaum karena mereka menghalang-halangi kamu dari Masjidilharam, mendorongmu berbuat aniaya (kepada mereka). dan tolong-menolonglah kamu dalam (mengerjakan) kebajikan dan takwa, dan jangan tolong-menolong dalam berbuat dosa dan pelanggaran. dan bertakwalah kamu kepada Allah, Sesungguhnya Allah amat berat siksa-Nya. ${ }^{12}$

Dilain ayat, misalnya dalam surah al-Nisa ayat 12 sebagai berikut:

Artinya: Dan bagimu (suami-suami) seperdua dari harta yang ditinggalkan oleh isteri-isterimu, jika mereka tidak mempunyai anak. jika Isteri-isterimu itu mempunyai anak, maka kamu mendapat seperempat dari harta yang ditinggalkannya sesudah dipenuhi wasiat yang mereka buat atau (dan) seduah dibayar hutangnya. para isteri memperoleh seperempat harta yang kamu tinggalkan jika kamu tidak mempunyai anak. jika kamu mempunyai anak, maka para isteri memperoleh seperdelapan dari harta yang kamu tinggalkan sesudah dipenuhi wasiat yang kaти buat atau (dan) sesudah dibayar hutang-hutangmu. jika seseorang mati, baik lakilaki maupun perempuan yang tidak meninggalkan ayah dan tidak meninggalkan anak, tetapi

${ }^{5}$ Warkum Sumitro, Asas-Asas Perbankan Islam dan Lembaga- Lembaga Terkait, (Jakarta: PT. Raja Grafindo Persada, 2002), hlm. 39; lihat Lemiyana, Pengaruh Produk Terhadap Keputusan Nasabah Perbankan Syariah (Studi Kasus Perbankan Syariah di Kota Palembang), (Jurnal I-Finance Vol. 4. No. 1. Juni 2018), hlm. 31

${ }^{6}$ Ropi Marlina, Yola Yunisa Pratami, Koperasi Syariah sebagai Solusi Penerapan Akad Syirkah yang Sah (Jurnal Amwaluna, Vol. 1 No. 2, Juli, 2017), hlm. 263-264

${ }^{7}$ Syi'ar Allah ialah: segala amalan yang dilakukan dalam rangka ibadat haji dan tempat-tempat mengerjakannya.

${ }^{8}$ Maksudnya antara lain ialah: bulan Haram (bulan Zulkaidah, Zulhijjah, Muharram dan Rajab), tanah Haram (Mekah) dan Ihram., maksudnya ialah: dilarang melakukan peperangan di bulan-bulan itu.

${ }^{9}$ Ialah: binatang (unta, lembu, kambing, biri-biri) yang dibawa ke ka'bah untuk mendekatkan diri kepada Allah, disembelih ditanah Haram dan dagingnya dihadiahkan kepada fakir miskin dalam rangka ibadat haji.

${ }^{10}$ Ialah: binatang had-ya yang diberi kalung, supaya diketahui orang bahwa binatang itu Telah diperuntukkan untuk dibawa ke Ka'bah.

${ }^{11}$ Dimaksud dengan karunia ialah: keuntungan yang diberikan Allah dalam perniagaan. keredhaan dari Allah ialah: pahala amalan haji.

${ }^{12}$ Departemen Agama RI, Al-Qur'an dan Terjemahannya (Semarang: Toha Putra, 2005), hlm. 156 
I-Economic Vol. 4. No 2. Desember 2018

Maqashid Koperasi Syariah .... Nurhadi

mempunyai seorang saudara laki-laki (seibu saja) atau seorang saudara perempuan (seibu saja), maka bagi masing-masing dari kedua jenis saudara itu seperenam harta. tetapi jika Saudara-saudara seibu itu lebih dari seorang, maka mereka bersekutu dalam yang sepertiga itu, sesudah dipenuhi wasiat yang dibuat olehnya atau sesudah dibayar hutangnya dengan tidak memberi mudharat (kepada ahli waris). ${ }^{13}$ (Allah menetapkan yang demikian itu sebagai) syari'at yang benar-benar dari Allah, dan Allah Maha mengetahui lagi Maha Penyantun. ${ }^{14}$

Juga berkaitan dengan kerja sama ada dalam surah Shaad ayat 24 sebagai berikut:

Artinya: Daud berkata: "Sesungguhnya dia telah berbuat zalim kepadamu dengan meminta kambingmu itu untuk ditambahkan kepada kambingnya. dan Sesungguhnya kebanyakan dari orang-orang yang berserikat itu sebahagian mereka berbuat zalim kepada sebahagian yang lain, kecuali orang-orang yang beriman dan mengerjakan amal yang saleh; dan amat sedikitlah mereka ini". dan Daud mengetahui bahwa kami mengujinya; maka ia meminta ampun kepada Tuhannya lalu menyungkur sujud dan bertaubat. ${ }^{15}$

Didukunng hadis yang diriwayatkan oleh Imam Abu Daud dan Ahmad sebagai berikut:

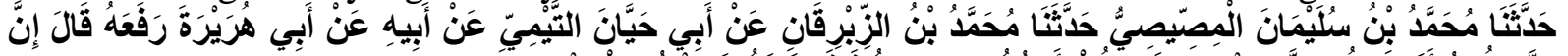

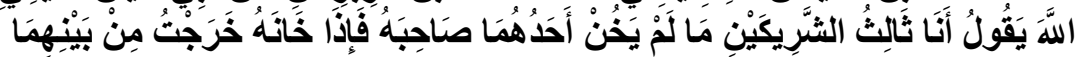

Artiny: Telah menceritakan kepada kami Muhammad bin Sulaiman Al-Mishshishi, telah menceritakan kepada kami Muhammad bin Al-Zibriqan, dari Abu Hayyan Al-Taimi, dari ayahnya dari Abu Hurairah dan ia merafa'kannya. Ia berkata; sesungguhnya Allah berfirman: "Aku adalah pihak ketiga dari dua orang yang bersekutu, selama tidak ada salah seorang diantara mereka yang berkhianat kepada sahabatnya. Apabila ia telah mengkhianatinya, maka aku keluar dari keduanya (HR. Abu Daud). ${ }^{16}$

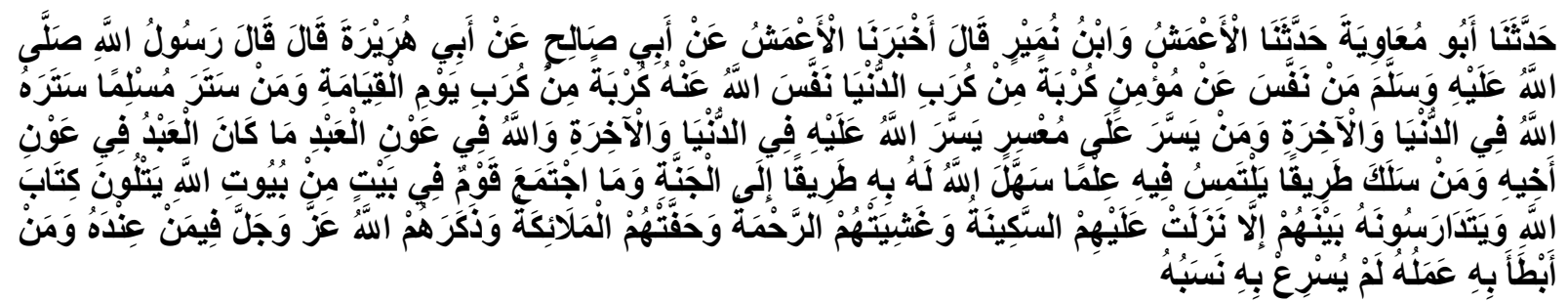

Artinya: Telah menceritakan kepada kami Abu Mu'awiyah telah menceritakan kepada kami Al-A'masy dan Ibnu Numair telah mengkabarkan kepada kami Al-A'masy dari Abu Shalih dari Abu Hurairah, dia berkata; Rasulullah saw bersabda: "Barangsiapa meringankan seorang mukmin dari kesulitan di dunia maka Allah akan meringankan baginya kesulitan di hari

\footnotetext{
${ }^{13}$ Memberi mudharat kepada waris itu ialah tindakan-tindakan seperti: a. mewasiatkan lebih dari sepertiga harta pusaka. b. berwasiat dengan maksud mengurangi harta warisan. sekalipun kurang dari sepertiga bila ada niat mengurangi hak waris, juga tidak diperbolehkan.

${ }^{14}$ Departemen Agama RI, Al-Qur'an, hlm. 117

${ }^{15}$ Ibid., hlm. 735

${ }^{16}$ Imam Abu Daud, Sunan Abu Daud, dalam Kitab : Jual beli, pada Bab : Jual beli persekutuan, No. Hadist : 2936. Dalam hadis yang lain Nabi Muhammad saw bersabda: Allah akan mengabulkan doa bagi dua orang yang bermitra selama di antara mereka tidak saling mengkhianati. (HR. Al-Bukhari).
} 
I-Economic Vol. 4. No 2. Desember 2018

Maqashid Koperasi Syariah .... Nurhadi

kiamat. Dan barangsiapa menutupi aib seorang muslim maka Allah akan menutupi aibnya di dunia dan di akhirat. Dan barangsiapa memudahkan bagi seorang yang kesusahan maka Allah akan memudahkan baginya di dunia dan di akhirat, dan Allah akan menolong seorang hamba selama ia mau menolong saudaranya. Barangsiapa meniti jalan dalam rangka menuntut ilmu maka Allah akan mempermudah baginya jalan menuju surga, dan tidaklah suatu kaum yang berkumpul di salah satu rumah dari rumah-rumah Allah, mereka membaca kitab Allah, dan mempelajarinya dengan sesama mereka kecuali akan diturunkan kepada mereka ketenangan, dilimpahkan kepada mereka rahmat, dikelilingi oleh para malaikat dan Allah swt akan menyebut-nyebut mereka di hadapan malaikat yang ada di sisi-Nya. Dan barangsiapa diperlambat oleh amalnya maka tidak akan bisa dipercepat oleh nasabnya (HR. Ahmad). ${ }^{17}$

Sejarah jejak koperasi berdasarkan prinsip syariah telah ada dalam Islam, hal itu dikenal sejak abad III Hijriyah di Timur tengah dan Asia Tengah yang secara teoritis dikemukakan oleh filsuf Islam, ${ }^{18}$ diriwayatkan bahwa Rasulullah saw pernah ikut dalam suatu kemitraan usaha semacam koperasi di antaranya dengan Saibin Syarik di Madinah. ${ }^{19}$ Mazhab Hanafiah, syafiiyah, hanabilah dan malikiyah menyetujui (membolehkan) Syirkah. Hanya saja ada beberapa jenis syirkah yang terdapat perbedaan pendapat diantara ke empat madzhab tersebut. ${ }^{20}$

Inti dari kegiatan koperasi tersebut adalah usaha bersama dengan penuh semangat saling tolong menolong dan seirama kompak tidak ada penghiyanatan di antara para anggota koperasi. Para anggota koperasi dalam melakukan pengelolaan koperasi bagaikan satu tubuh, di mana satu anggota koperasi diibaratkan satu organ anggota tubuh manusia (kamatsalil jasadi). Setiap organ tubuh dengan organ tubuh yang lain terjalin hubungan yang harmonis saling asah asih dan asuh. ${ }^{21}$

Fakta mendasar dan isu popular, masih sering timbul dalam wacana perkoperasian adalah bahwa koperasi merupakan organisasi ekonomi berbasis orang atau keanggotaan (membership based association) yang kini cenderung menjadi substantive power sebagai tulang punggung perekonomian di negara-nara maju sekalipun seperti terlihat dalam perkembangan dan pengembangan koperasi di Denmark, AS, Singapura, Korea, Jepang, Taiwan, dan Swedia, meskipun pada mulanya dalam pengalaman empiris hanya sebagai countervailing power (kekuatan pengimbang) terhadap kapitalisme swasta di bidang ekonomi yang didominasi oleh perusahaan berdasarkan modal persahaman (equity based association) yang sering menjadi sapi perahan bagi pemilik modal (share holders) dengan system dan

\footnotetext{
${ }^{17}$ Imam Ahmad, Musnad Ahmad bin Hambal, dalam Kitab : Sisa Musnad sahabat yang banyak meriwayatkan hadits, pada Bab : Musnad Abu Hurairah Radliyallahu 'anhu, No. Hadist : 7118

${ }^{18}$ Imam al-Farabi, Imam Al-Syarakhsi dalam al-Mabsuth sebagaimana dinukil oleh M. Nejatullah Siddiqi dalam Partnership and Profit Sharing in Islamic Law.

${ }^{19}$ Dakwatuna, Prinsip Dasar Koperasi Syariah, artikel wibesitw online lihat dalam alamat sebagai https://www.dakwatuna.com/2009/08/08/3360/prinsip-dasar-koperasi-syariah/\#axzz5PNbb2Ks1.diakses tgl 25 agustus 2018

${ }^{20}$ Ilmam Aziz, Pemasaran Koperasi Syariah, lihat dalam wibesite online alamat https://aziz27.wordpress.com/2009/06/29/pemasaran-koperasi-syariah/.diakses tgl 27 agustus 2018.

${ }^{21}$ Ali Imron Hasan, Aktualisasi Prinsip Prinsip Syariah Dalam Berkoperasi Di Pondok Pesantren, lihat dalam wibesite online alamat http://imronmangkang.blogspot.com/2013/10/aktualisasi-prinsip-prinsipsyariah.html.diakses tgl 26 agustus 2018 .
} 
mekanisme targeting yang memeras pengelola. ${ }^{22}$ Baik negara maju maupun negara berkembang dewasa ini telah menerima kehadiran koperasi, terutama dalam rangka menata golongan ekonomi kecil yang lemah posisi ekonominya. Sebagian negara berkembang dewasa ini bahkan secara langsung memilih koperasi untuk mengatasi ketimpangan ekonomi. ${ }^{23}$

Secara etimologi kata koperasi berasal dari bahasa inggris yaitu coperation yang artinya bekerja sama. Sedangkan dari segi terminologi, koperasi ialah suatu perkumpulan atau organisasi yang beranggotakan orang-orang atau badan hukum yang bekerja sama dengan penuh kesabaran untuk meningkatkan kesejahteraan anggota atas dasar sukarela secara kekeluargaan. ${ }^{24}$ Sebagian ulama menyebut koperasi dengan syirkah ta'awuniyah (persetujuan kerjasama tolong menolong) yaitu suatu perjanjian kerjasama antara dua orang atau lebih, yang satu pihak menyediakan modal usaha sedangkan pihak lain melakukan usaha atas dasar membagi untung menurut perjanjian. Dalam koperasi ini terdapat unsur mudharabah karena satu pihak memiliki modal dan pihak lain melakukan usaha atas modal tersebut. ${ }^{25}$

Bapak koperasi Bung Hatta, koperasi sebagai social capital (ekonomi social), memilki 7 nilai prinsip sebagai spirit koperasi yaitu: ${ }^{26}$

1) Kebenaran untuk menggerakkan kepercayaan (trust).

2) Keadilan dalam usaha bersama.

3) Kebaikan dan kejujuran mencapai perbaikan.

4) Tanggung jawab dalam individualitas dan solidaritas.

5) Paham yang sehat, cerdas, dan tegas.

6) Kemauan menolong diri sendiri serta menggerakkan keswasembadaan dan otoaktiva.

7) Kesetiaan dalam kekeluargaan.

Di Indonesia, koperasi berbasis nilai Islam lahirlah pertama kali dalam bentuk paguyuban usaha bernama Syarikat Dagang Islam (SDI). DSI didirikan H. Samanhudi di Solo, Jawa Tengah, yang beranggotakan para pedagang muslim, yang mayoritas pedagang batik. Meskipun pada perkembangannya, SDI berubah menjadi Syarikat Islam yang bernuansa gerakan politik. ${ }^{27}$ Namun konsep kerjasama dalam bentuk syirkah Islam dan syirkah Modern ada kesamaan, sama-sama dibentuk oleh para pihak (anggota) atas kesepakatan mereka sendiri (para anggota) untuk mencari keuntungan secara proporsional (saling menguntungkan). ${ }^{28}$

${ }^{22}$ Kosmi Karawang, Sejarah Koperasi Syariah, lihat dalam wibesite online alamat http://www.kosmipro.com/2018/02/posting-4.html.diakses tgl 26 agustus 2018.

${ }^{23}$ Masbodik, Koperasi dalam Kacamata Syariah, lihat dalam wibesite online alaat https://masbodik.wordpress.com/2008/08/25/koperasi-dalam-kacamata-syariah/.diakses tgl 26 agustus 2018.

${ }^{24}$ Ropi Marlina, Yola Yunisa Pratami, Koperasi Syariah, hlm. 273

${ }^{25} \mathrm{Al}-Z a h r a h, \quad K o p e r a s i$ dalam Pandangan Islam, lihat dalam wibesite online alamat http://khamsatul.blogspot.com/2012/01/koperasi-dalam-pandangan-islam.html.diakses tgl 27 agustus 2018.

${ }^{26}$ Muhammad Hatta, Membangun Koperasi dan Koperasi Membangun (Jakarta: Inti Idayu Press, 1987), hlm. 22-25

${ }^{27}$ Dalam konteks budaya kemitraan, penelitian Afzalul Rahman yang dirilis dalam Economic Doctrines of Islam, koperasi tipe kemitraan modern Barat mirip dengan kemitraan Islam. Bahkan, telah dipraktikan oleh umat Islam hingga abad 18.

${ }^{28} \mathrm{Al}$-Hikmah, Koperasi dalam Islam, lihat dalam wibesite online alamat http://www.alhikmah.ac.id/koperasi-dalam-islam-2/.diakses tgl 26 agustus 2018. 
I-Economic Vol. 4. No 2. Desember 2018

Maqashid Koperasi Syariah .... Nurhadi

Tataran aplikasi dari tujuh nilai spirit koperasi yang menjiwai kepribadian koperasi versi Bung Hatta, dituangkan dalam tujuh prinsip operasional koperasi secara internal dan eksternal yaitu:

1) Keanggotaan sukarela dan terbuka.

2) Pengendalian oleh anggota secara demokratis.

3) Partisipasi ekonomis anggota.

4) Otonomi dan kebebasan.

5) Pendidikan, pelatihan dan informasi.

6) Kerjasama antar koperasi.

7) Kepedulian terhadap komunitas.

Menurut Rustam Effendi dkk, dalam penelitiannya, bahwa konsep koperasi Bung Hatta, meliputi: (a) Koperasi merupakan usaha bersama berdasar atas asas kekeluargaan; (b) Konsep koperasi Bung Hatta didasarkan kepada semangat kolektivisme masyarakat yang sudah ada di dalam kebiasaan masyarakat Indonesia; (c) Koperasi bukan hanya merupakan badan ekonomi, akan tetapi juga merupakan badan sosial yang bertanggung jawab terhadap masyarakat disekitarnya; (d) Koperasi juga sebagai wadah untuk mendidik para anggotanya untuk memiliki sifat solidaritet (setia berekutu) dan individualitet (kesadaran akan harga diri sendiri); (e) Koperasi memberikan pendidikan moril agar anggotanya memiliki cita-cita yang tinggi; dan (f) Koperasi bertugas memperbanyak produksi, memperbaiki kualitas, dan memperbaiki distribusi. ${ }^{29}$

Sedangkan analisis konsep koperasi Bung Hatta dalam perspektif ekonomi syariah menurut Rustam Effendi dkk, yaitu: (a) Adanya kesamaan antara konsep koperasi Bung Hatta dengan konsep ekonomi syariah, yaitu tentang konsep syirkah (usaha bersama), menciptakan persaudaraan dan keadilan sesama, prinsip manfaat, prinsip mashlahah, nilai khilafah, distribusi, dan ta'awun; (b) Terdapat perbedaan antara konsep koperasi Bung Hatta dengan konsep ekonomi syariah, yaitu landasan konsep koperasi Bung Hatta yaitu tersapat pada Undang-Undang Dasar 1945 pasal 33 dan Undang-Undang Republik Indonesia nomor 25 tahun 1992. Sedangkan konsep ekonomi syariah yang berlandaskan Al-Qur'an dan hadis dan mencantumkan dalil di setiap teorinya; (c) Konsep koperasi Bung Hatta memiliki keterkaitan dengan konsep ekonomi syariah. Hal ini dapat diketahui dari beberapa persamaan konsep koperasi Bung Hatta yang ternyata terdapat nilai-nilai ekonomi syariah; dan (d) Konsep koperasi Bung Hatta memberikan kontribusi terhadap perkoperasian di Indonesia dan ekonomi syariah. ${ }^{30}$

\section{Paradigma Idiologi Maqashid Syariah}

Imam Al-Syathibi, dalam kitab al-Muwafaqat mencatat ada empat aliran dalam pemahaman al-Qur'an dan hadits, yaitu Zhahiriyah (literal), Bathiniyah, Al-Muta ‘ammiqun fi al-Qiyas (rasionalis dan cenderung liberal) dan al-Rasikhun fi al-'Ilm (mendalam ilmunya dan moderat). ${ }^{31}$

${ }^{29}$ Rustam Effendi, dkk, Konsep Koperasi Bung Hatta Dalam Perspektif Ekonomi Syariah, (Jurnal AlHikmah Vol. 15 No. 1 April 20180, hlm. 133

${ }^{30}$ Ibid.

${ }^{31}$ Abu Ishak al-Syathibi, al-Muwafaqat fi Usul Syariah, (Dar al-Kutub al-Ilmiyah, Beirut-Libanon), hlm. 
I-Economic Vol. 4. No 2. Desember 2018

Maqashid Koperasi Syariah .... Nurhadi

Pertama adalah Al-Ittijah al-Lafzdi (Mazhab Zhahiriyah/Tektual), yaitu aliran Zhahiriyah yang merupakan sebuah mazhab yang berlandaskan pada al-Qur'an, sunnah dan ijma', tetapi menolak intervensi akal dalam bentuk qiyas, ta 'ill, istihsan dan lain sebagainya. Aliran Zhahiriyah pun berpendapat bahwa pada dasarnya 'illat hukum tidak ada kecuali ada dalilnya, sebab suatu teks hukum (nash) dapat menentukan adanya hukum menurut bentuk teks itu sendiri, bukan karena ada 'illat-nya dan hal ini bukan dari bagian obyek nash. ${ }^{32}$ Melalui proses ta'lil (pencarian 'illat), hukum beralih dari bentuknya menuju makna hukum atau 'illat, seperti peralihan makna hakikat ke makna majaz karena ada alasannya. Zhahiriyah, sebutan bagi para penganut mazhab ini, terambil dari nama tokoh panutannya, Daud bin Ali al-Zhahiri. Muncul pertama kali pada paruh pertama abad ketiga hijriah. ${ }^{33}$ Dalam memahami teks keagamaan zhahiriyah berpegangan kepada tiga prinsip dasar: ${ }^{34}$

1) Keharusan berpegang teguh pada lahiriah teks, dan tidak melampauinya kecuali dengan teks yang zhahir lainnya atau dengan konsensus (ijma') yang pasti. Penggunaan akal tidak diperkenankan.

2) Maksud teks yang sebenarnya terletak pada yang zhahir, bukan di balik teks yang perlu dicari dengan penalaran mendalam. Demikian pula mashlahah yang dikehendaki syara:

3) Mencari sebab di balik penetapan syariat adalah sebuah kekeliruan. Ibnu Hazm, salah seorang tokohnya berkata : Seseorang tidak boleh mencari sebab dalam agama, karena sesungguhnya sesuatu atas kehendak Allah, dan tidak diperkenankan mengatakan 'ini' adalah sebab ditetapkannya 'itu', kecuali ada nash tentang itu. (La yus'alu 'amma yaf alu wahum yus ‘alun). ${ }^{35}$

Dalam kajian pemikiran Islam, aliran Zhahiriyah berkembang sampai saat ini. Mereka mewarisi kejumudan Zhahiriyah masa lampau. Di antara ciri aliran Zhahiriyah masa kini dalam pemahaman teks adalah: ${ }^{36}$

1) Memahami teks secara literal (harfiyyah) dan kaku, tanpa melihat `illat atau Maqashid di balik teks.

2) Cenderung keras (tasyaddud), mempersulit dan berlebihan (al-Ghuluww)

3) Menganggap dirinya yang paling benar, dan lainnya salah

4) Tidak mentolerir perbedaan pendapat atau pandangan

5) Berburuk sangka karena sempitnya cara pandang dalam syariat dan bahkan mengkafirkan pandangan yang berbeda ${ }^{37}$

Banyak hasil ijthad kelompok Zhahiriyah dalam memahami teks yang dinilai keliru oleh para ulama karena mereka terlalu sempit dalam memahami nash syariat. Hal ini disebabkan antara lain karena mereka tidak mau menggunakan akal dalam pengambilan

${ }^{32}$ Nurhadi, Konsep Hikmat al-Tasyri sebagai asas Ekonomi dan Keuangan Bisnis Islam dalam Kitab Hikmat al-Tasyri wa falsafathu Karya Ali Ahmad l-Jurjawi (1866-1961 M), Disertasi UIN Suska Riau, 2018), hlm. 43

${ }^{33}$ Abu Ishaq al-Syathibi, al-Muwafaqat, hlm. 27

${ }^{34}$ Ibid., hlm.2 8

${ }^{35}$ Oni Syahroni dan Adiwarmab Karim, Maqashid Bisnis dan Keuangan Islam (Jakarta: Rajawali Pers, 2016), hlm. 26-30

${ }^{36}$ Abu Ishaq al-Syathibi, al-Muwafaqat, hlm. 31

${ }^{37}$ Oni Syahroni dan Adiwarmab Karim, Maqashid, hlm. 27-39 
I-Economic Vol. 4. No 2. Desember 2018

Maqashid Koperasi Syariah .... Nurhadi

hukum dengan memperluas cakupan zhahir, sehingga al-Qur'an tidak lagi mampu mengantisipasi berbagai kemashlahahan yang timbul kemudian. ${ }^{38}$

1) Jumud dan tidak mengikuti perkembangan zaman, sehingga bertentangan dengan fungsi alQur'an sebagai kitab abadi di setiap ruang dan waktu. Teks al-Qur'an terbatas, sementara peristiwa dan kejadian yang dialami manusia selalu berkembang.

2) Tidak sejalan dengan rasionalitas al-Qur'an karena hanya membatasi pemahaman pada logika bahasa. ${ }^{39}$

Kedua, Mazhab Bathiniyah yaitu sebuah nomenklatur bagi sekian banyak kelompok yang pernah ada dalam sejarah Islam. Muncul pertama kali pada masa al-Ma`mun (w 218), salah seorang penguasa Abbasiyah, dan berkembang pada masa al-Mu'tashim (w 227). Sebagian ulama mensinyalir, prinsip-prinsip dasar yang digunakan dalam memahami teksteks keagamaan bersumber dari kalangan Majusi yang mempengaruhi salah satu dari golongan umat Islam yaitu mazhab Syi'ah. Aliran ini dinamakan Bathiniyah karena mereka meyakini adanya Imam yang gaib. Mereka mengklaim ada dua sisi dalam syariat; zhahir dan bathin. Manusia hanya mengetahui yang zhahir, sedang yang bathin hanya diketahui oleh Imam, tolak ukur penafsiran akan bathin al-Qur'an atau Hadist adalah kepada Imamiyah. ${ }^{40}$

Pola yang digunakan Bathiniyah dalam memahami teks-teks keagamaan;

1) Tujuan dan maksud dari sebuah teks (al-Qur'an dan hadis) bukan pada makna zhahir yang diperoleh melalui kaidah-kaidah kebahasaan dan konteks penyebutan, tetapi terletak pada makna di balik simbol zhahirnya.

2) Mereka mengkultuskan makna bathin sebuah teks dan mengingkari zhahir teks sehingga banyak hukum-hukum syar ${ } i$ yang diabaikan, bahkan tidak ditaati lagi. ${ }^{41}$

Dalam perkembangannya, mazhab Bathiniyah berpendapat bahwa untuk menetapkan hukum-hukum agama walaupun harus berbenturan dengan nash-nash yang tsawabit, bahkan meruntuhkan sekalipun. Ketentuan-ketentuan yang ada dianggap tidak lagi dapat memenuhi kemashlahatan manusia yang terus berkembang. ${ }^{42}$ Keinginan untuk menyelaraskan nash dengan realita dilakukan melalui upaya mencari maqashid syari ah yang diduga berada di balik simbol-simbol teks tanpa ada ketentuan yang mengaturnya, tentunya dengan ukuran akal manusia modern. Siapa saja dapat melakukannya. Dengan dalih kemashlahahan (almashlahah) manusia modern terjadi upaya meruntuhkan syari ah seperti pada hukum keluarga, warisan, hudud dan lain sebagainya. Teks-teks yang ada harus dipahami sebatas ruang dan konteks pewahyuannya, dengan kata lain disesuaikan dengan sabab nuzulnya. ${ }^{43}$

Yusuf al-Qaradhawi menamakan kelompok ini dengan "al-Mu aththilat al-Judud" (Neo-Mu`aththilah). Kalau mu`aththilah klasik bermain pada tataran akidah, neo-mu`aththilah bermain pada tataran syari ah .

\footnotetext{
${ }^{38}$ Nurhadi, Konsep Hikmat al-Tasyri, hlm. 44

${ }^{39}$ M. Supri Assyagily, Aliran-Aliran Maqashid al-Syariah, lihat dalam artikel onlline wibesite http://orientalisstudies.blogspot.co.id/2014/10/aliran-aliran-maqasid-al-Syariah.html,dldiakses Tanggal 24 Januari 2017 Jam 06.00 Wib.

${ }^{40}$ Ibid. Lihat juga Abu Ishaq al-Syathibi, al-Muwafaqat, hlm. 33

${ }^{41}$ Abu Ishaq al-Syathibi, al-Muwafaqat, hlm. 34

${ }^{42}$ Nurhadi, Konsep Hikmat al-Tasyri, hlm. 45

${ }^{43} \mathrm{Abu}$ Ishaq al-Syathibi, al-Muwafaqat, hlm. 35
} 
I-Economic Vol. 4. No 2. Desember 2018

Maqashid Koperasi Syariah .... Nurhadi

Secara umum kelompok ini bercirikan tidak mendalami sumber, prinsip dan hukum syari ah dengan baik, serta memiliki keberanian mengungkap pendapat meski tidak didukung argumentasi yang kuat. Pijakan dalam memahami teks :

1) Mengedepankan akal dari pada wahyu. Akal dapat menentukan mana yang lebih mashlahah untuk dilakukan sampaipun harus berbenturan dengan nash syar `iy.

2) Dengan dalih mashlahah, Umar bin Khattab telah mengalahkan nash seperti pada kasus almu'allafah qulubuhum yang tidak diberi zakat, menafikan hukum potong tangan saat paceklik terjadi dan lainnya.

3) Ungkapan yang sering disebut berasal dari Ibnul Qayyim, "di mana ada mashlahah di situ ada syari 'ah ", padahal ungkapan tersebut berlaku pada kasus yang tidak ada nashnya, atau ada mengandung berbagai kemungkinan yang dapat ditentukan melalui yang lebih mashlahah. Ungkapan yang tepat, "di mana ada syari 'ah di situ ada mashlahah".

4) Teks-teks yang ada harus dipahami sebatas ruang dan konteks pewahyuannya, dengan kata lain disesuaikan dengan sabab nuzulnya. Al-'Ibratu bi al-khushush al-Sabab, la bi 'Umum alLafzhi, demikian ungkapan yang sering digunakan. ${ }^{44}$

Karena itu Imam Ghazali, seperti dikutip al-Syathibi, mendudukkan mereka pada aliran yang keliru dalam menafsirkan dan memaknai teks wahyu, bahkan kerusakan yang mereka lakukan. ${ }^{45}$ Al-Razi menyatakan bahwa ini jauh lebih parah dari tindakan orang kafir karena mereka merusak syariat Islam dengan sebutan Islam itu sendiri. ${ }^{46}$

Ada beberapa kekeliruan yang dilakukan aliran Bathiniyah, di antaranya: ${ }^{47}$

1) Tidak memiliki perangkat pemahaman yang benar. Mereka tidak menggunakan kaidah-kaidah kebahasan dan pokok-pokok ilmu tafsir sebagai sandaran dalam memahami al-Qur'an, meskipun Al-Qur'an diturunkan dalam bahasa Arab dan baru dapat dipahami maknanya jika sesuai dengan prinsip-prinsip bahasa Arab.

2) Mengira ada yang kurang dalam syariat, dan baru sempurna dipahami secara bathin yang hanya bisa dilakukan oleh imam yang ma`shum.

3) Mengedepankan akal dari pada syariat yang dianggapnya kurang memadai dan melepaskannya tanpa kendali untuk menyelami lautan makna bathin. Oleh karena itu, keragaman pandangan yang tidak didasari pada kaidah yang jelas akan menimbulkan kekacauan. ${ }^{48}$

Ketiga: aliran Al-Ittijah Attaqwili (Mazhab Ra'yu/Filasafat Logika) yaitu sebagian ulama menisbatkan kecenderungan ini kepada Imam Sulaiman al-Thufi (w $716 \mathrm{H})$ yang dikenal dengan teori mashlahah yang dipahaminya sebagai "sebab yang dapat mengantarkan kepada tujuan syariat Allah swt dalam ibadah (al- `ibadat) dan mu`amalah (al-Mu'amalah)". ${ }^{49}$

Pendapatnya yang sangat berbeda dengan jumhur ulama dan mendapat kritikan tajam: "Jika ada mashlahah yang bertentangan dengan nash yang terkait dengan mu'amalah (adat),

${ }^{44}$ M. Supri Assyagily, Aliran-Aliran Maqashid, Loc. Cit.

${ }^{45}$ Abu Ishaq al-Syathibi, Muwafaqat, juz II, 75.

${ }^{46} \mathrm{Al}-$ Razi (1999M/1420H), Munazarat Fakhr al-Din al-Raziy, juz II, hlm. 368

${ }^{47}$ Nurhadi, Konsep Hikmat al-Tasyri, hlm. 46

${ }^{48}$ Ahmad al-Mursi Husain Jauhar, Maqashid Syariah, (Amzah, Jakarta 2009). Lihat juga M. Supri Assyagily, Aliran-Aliran Maqashid al-Syariah, http://orientalisstudies.blogspot.co.id/2014/10/aliran-aliran-maqasidal-Syariah.html,dldiakses Tanggal 24 Januari 2017 Jam 06.00 Wib.

${ }^{49}$ Maman Suherman, Aliran Ushul Fiqh Dan Maqashid Syari'ah, Jurnal Demo : Purchase From Www.APDF.Com To Remove The Watermark, hlm. 359. Lihat juga Abu Ishak al-Syathibi, al-Muwafaqat, hlm. 37 
I-Economic Vol. 4. No 2. Desember 2018

Maqashid Koperasi Syariah .... Nurhadi

maka mashlahah harus dikedepankan daripada nash". Menurut al-Thufi, hubungan antara mashlahah dan nash (dalil syar'i) berkisar pada tigal hal ;

1) Dalil syar i sejalan dengan mashlahah, seperti dalam penetapan hudud terhadap pelaku pembunuhan, pencurian, qadzaf dan lainnya. ${ }^{50}$

2) Jika tidak sejalan tetapi memungkinkan untuk dikompromikan melalui takhshish atau taqyid maka keduanya dapat digunakan dalam batas-batas tertentu.

3) Jika terjadi benturan antara mashlahah dan nash dan tidak bisa dikompromikan, maka mashlahah harus dikedepankan dan nash ditinggalkan. ${ }^{51}$

Aliran ini-pun menyatakan bahwa mashlahah harus dikedepankan, karena akal dapat menalar dan membedakan mashlahah manusia tanpa perlu bantuan syara'. Mashlahah dapat diketahui secara pasti melalui kebiasaan, sedangkan nash-nash syar'iy tidak dapat menjelaskannya karena banyak interpretasi dan kemungkinan. Ukurannya adalah, hukum mu amalat sejalan dengan akal dan kebiasaan serta mewujudkan manfaat, baik ketika sejalan dengan nash maupun bertentangan.

Menurut al-Syathibi dalam al-Muwafaqat-nya, ada beberapa kekeliruan yang terdapat dalam aliran ini, di antaranya ialah : 52

1) Akal memiliki keterbatasan untuk menjangkau semua mashlahah manusia secara sempurna. Apa yang diduga akal mendatangkan mashlahah boleh jadi justru sebaliknya. Pengetahuannya sangat terbatas (QS. Al-Isra : 85, QS. Al-Nahl : 8 dan lain-lain. Melepaskan akal untuk menalar tanpa kendali sama tercelanya dengan mengekang akal untuk tidak berpikir.

2) Akal mengikuti syara, bukan sebaliknya. ${ }^{53}$

Kendati berbeda, mereka sepakat mengatakan, sumber penetapan hukum adalah syari at, baik yang tertuang dalam bentuk teks maupun hasil ijtihad . sebagaimana pernyataan mereka, bahwa:

1) Kemashlahahan dalam mu'amalah duniawi ada yang tidak diketahui akal, dan hanya dapat diketahui melalui wahyu, karena itu perlu berpegang pada ketentuan syariat untuk mencegah kekacauan dan kebimbangan.

2) Hak-hak mukallaf (hamba) tidak lepas dari hak Tuhan. Al-Thufi membedakan antara ibadat yang dianggap hak Tuhan sehingga perlu berpegang pada ketentuan syara, dan muamalat yang merupakan hak hamba sehingga yang menjadi tolok ukur adalah kemashlahahan hamba walaupun bertentangan dengan nash.

3) Al-Syathibi mengatakan, "Dalam setiap bentuk taklif terdapat hak Allah swt". Bentuk hukuman hudud jika telah sampai ke tangan hakim, selain qishash, qadzaf dan mencuri, tidak dapat digugurkan meski telah dimaafkan oleh pihak terkait. ${ }^{54}$

${ }^{50}$ Abu Ishaq al-Syathibi, Muwafaqat, hlm. 39

${ }^{51}$ Oni Syahroni dan Adiwarmab Karim, Maqashid, hlm. 30-33. At-Thufi berpandangan bahwa mashlahah mursalah sebagai istinbat hukum islam, dengan alasan : (1). Bahwa akal dapat menggali terhadap sesuatu (termasuk baik/kemaslahatan dan buruk/kemudaratan), sehingga akal dapat menghasilkan sebuah prodak sesuatu yang katagorinya manfaat (kemaslahatan) dan sesuatu yang kategorinya mafsadah (kerusakan). (2). Mashlahah merupakan dalil syari'ah tersendiri yang lepas dari dalil-dalil nash. (3). Kemaslahatan merupakan dalil yang kuat dibanding nash, karena pada esensinya nash itu kandungan sebuah kemaslahatan. (4). Kemaslahatan hanya diberlakukan dalam bidang mu'amalah saja. (Amin Farih, Kemaslahatan dan Pembaharuan Hukum Islam, (Semarang : Walisongo Press, 2008), hlm 191-192.

${ }^{52}$ Nurhadi, Konsep Hikmat al-Tasyri, hlm. 47

${ }^{53}$ Abu Ishaq al-Syathibi, Muwafaqat, hlm. 26-27 
I-Economic Vol. 4. No 2. Desember 2018

Maqashid Koperasi Syariah .... Nurhadi

4) Dalam syariat tidak ada yang bertentangan dengan akal. Mengedepankan mashlahah dari pada nash mengesankan ada sekian mashlahah yang bertentangan syariat. Ini berlawanan dengan kenyataan bahwa agama (syari at) sejalan dengan akal dan fitrah manusia.

5) Tidak ada pertentangan antara nash dan mashlahah. Kemashlahahan yang hakiki terletak pada cakupan Maqashid syari ah, sehingga tidak mungkin ada pertentangan antara keduanya. ${ }^{55}$

Keempat aliran Al-Ittijah al-Maqashidi (Mazhab Wasath/Moderat) yaitu terlalu berpegang pada lahir teks dan mengesampingkan mashlahah atau maksud di balik teks berakibat pada kesan Syariat Islam tidak sejalan dengan perkembangan zaman dan jumud dalam menyikapi persoalan. Sebaliknya terlampau jauh menyelami makna bathin akan berakibat pada upaya menggugurkan berbagai ketentuan syariat. ${ }^{56}$

Sikap 'tengahan' inilah yang diharapkan dapat mengawal pemaknaan al-Qur'an dan hadits. Rasulullah shallallahu `alayhi wasallam bersabda :

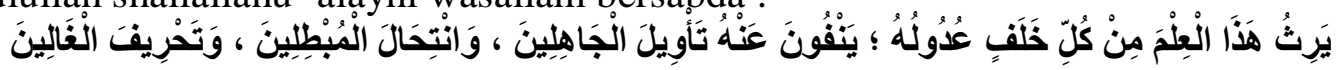

Artinya: "Ilmu (Al-Qur'an) akan selalu dibawa pada setiap generasi oleh orang-orang yang moderat ('udul); mereka itu yang memelihara Al-Qur'an dari pena'wilan mereka yang bodoh, manipulasi mereka yang batil dan penyelewengan mereka yang berlebihan".

Secara umum ajaran Islam bercirikan moderat (wasath); dalam akidah, ibadah, akhlak dan mu amalah. Ciri ini disebut dalam al-Qur'an sebagai al-Shirath al-Mustaqim (jalan lurus/ kebenaran), yang berbeda dengan jalan mereka yang dimurkai (al-maghdhub ‘laihim) dan yang sesat (al-dhullun) karena melakukan banyak penyimpangan. ${ }^{57}$

Wasathiyyah (moderasi) berarti keseimbangan di antara dua sisi yang sama tercelanya; 'kiri' dan 'kanan', berlebihan (ghuluww) dan keacuhan (taqshir), literal dan liberal, seperti halnya sifat dermawan yang berada di antara sifat pelit (taqtir/ bakhil) dan boros tidak pada tempatnya (tabdzir). Karena itu kata wasath biasa diartikan dengan 'tengah'. Dalam sebuah hadis Nabi saw, ummatan wasathan ditafsirkan dengan ummatan 'udulan. ${ }^{58}$

Ciri sikap moderat dalam memahami teks $:^{59}$

1) Memahami agama secara menyeluruh (komperhensif), seimbang (tawazun) dan mendalam.

2) Memahami realitas kehidupan secara baik

3) Memahami prinsip-prinsip syari at (Maqashid al-syariah) dan tidak jumud pada tataran lahir.

4) Terbuka dan memahami etika berbeda pendapat dengan kelompok-kelompok lain yang seagama, bahkan luar agama, dengan senantiasa "mengedepankan kerjasama dalam hal-hal yang disepakati dan bersikap toleran pada hal-hal yang diperselisihkan".

5) Menggabungkan antara "yang lama" (al-ashalah) dan "yang baru" (al-mu 'asharah)

6) Menjaga keseimbangan antara tsawabit dan mutaghayyirat. Tsawabit dalam Islam sangat terbatas seperti, prinsip-prinsip akidah, ibadah (rukun Islam), akhlaq, hal-hal yang diharamkan secara qath iy (zina, qatl, riba dsb). Mutaghayyirat; hukum-hukum yang ditetapkan dengan nash yang zhanniyy (tsubut atau dilalah)

\footnotetext{
${ }^{54}$ Ibid., hlm. 27-28

${ }^{55}$ M. Supri Assyagily, Loc. Cit.

${ }^{56}$ Maman Suherman, Aliran, hlm. 359

${ }^{57}$ Nurhadi, Konsep Hikmat al-Tasyri, hlm. 48

${ }^{58}$ Maman Suherman, Aliran, hlm. 360.

${ }^{59}$ Abu Ishaq al-Syathibi, Muwafaqat, hlm. 33-35
} 
I-Economic Vol. 4. No 2. Desember 2018

Maqashid Koperasi Syariah .... Nurhadi

7) Cenderung memberikan kemudahan dalam beragama. ${ }^{60}$

Adapun pijakan Thariq al-Jam 'i dalam memahami teks adalah: ${ }^{61}$

1) Memadukan antara yang zhahir dan yang bathin secara seimbang dan tidak memisahkan makna bathin dengan zhahir nash.

2) Memahami nash sesuai dengan bahasa, tradisi kebahasaan dan pemahaman bangsa Arab (alSyari ah Ummiyyah)

3) Membedakan antara makna syar $i$ dan makna bahasa. Makna syar `i dimaksud adalah yang ditetapkan oleh agama, bukan makna yang berkembang kemudian. Kata al-Sa `ihun pada QS. Al-Taubah : 112 dalam Al-Qur'an bermakna orang yang berpuasa atau berhijrah, bukan mereka yang berwisata.

4) Memperhatikan hubungan (korelasi/munasabah) antara satu ayat dengan lainnya, sehingga tampak sebagai satu kesatuan.

5) Membedakan antara makna haqiqiy dan majaziy melalui proses ta'wil yang benar. Pada dasarnya teks harus dipahami secara haqiqiy. Suatu ungkapan (kalam) dimungkinkan untuk dipahami secara majaziy bila memenuhi tiga syarat berikut $:^{62}$

a) Ada hubungan yang erat antara makna zhahir sebuah teks dengan makna lain yang dituju

b) Ada qarinah/konteks/dalil (maqaliyyah atau haliyah) yang menunjukkan penggunaan makna majaziy

c) Ada tujuan/hikmah di balik penggunaan makna majaziy yang ingin dicapai oleh pembicara (mutakallim) ${ }^{63}$

6) Memperhatikan hak-hak al-Qur'an yang harus dipahami oleh setiap yang akan menafsirkannya, yaitu antara lain : pandangan komprehensif terhadap al-Qur'an, memahami makna ragam qira ‘at yang ada, memahami retorika dan konteks (siyaq) al-Qur'an, memperhatikan sebab nuzul dan tradisi bahasa al-Qur'an, mengerti ayat-ayat yang musykil atau terkesan kontradiksi. ${ }^{64}$

\section{Kerangka Teori Koperasi Syariah}

Salah satu bentuk kerjasama ekonomi yang paling cocok untuk memberdayakan rakyat kecil adalah koperasi. Karena di dalam koperasi dapat ditemukan prinsip dan nilai-nilai kebersamaan, gotong royong dan kesejahteraan bersama. Bung Hatta memberikan perhatian khusus terhadap koperasi sebagai kerjasama ekonomi yang ideal ${ }^{65}$ karena koperasi adalah

${ }^{60}$ Oni Syahroni dan Adiwarmab Karim, Maqashid, hlm. 33-36

${ }^{61}$ Abu Ishaq al-Syathibi, Muwafaqat, hlm. 37-43

${ }^{62}$ Nurhadi, Konsep Hikmat al-Tasyri, hlm. 49

${ }^{63} \mathrm{Abu}$ Ishaq al-Syathibi, Muwafaqat, hlm. 45

${ }^{64}$ M. Supri Assyagily, Aliran-Aliran Maqashid al-Syariah, lihat dalam artikel online wibesite http://orientalisstudies.blogspot.co.id/2014/10/aliran-aliran-maqasid-al-Syariah.html,dldiakses Tanggal 24 Januari 2017 Jam 06.00 Wib.

${ }^{65}$ Menurut Anwar Abbas: Lembaga usaha yang mendapat tempat sentral dalam sistem ekonomi yang dikembangkan Hatta ialah koperasi”. Tetapi, ini tidakhlah berarti bahwa lembaga-lembaga usaha lainnya seperti lembaga yang diusahakan oleh pemerintah dan swasta tidak mendapat perhatian dari Hatta karena ketiga pelaku tersebut menurut Hatta adalah menjadi pilar dalam perekonomian Indonesia. Namun yang perlu mendapat perhatian di sini, bahwa konsep dan kehadiran koperasi bagi Hatta buakanlah sesuatu yang di dasarkan kepada idealisme semata, tetapi juga merupakan dari realitas keadaan ekonomi masyarakat pada waktu itu yang memerlukan kehadiran struktur perekonomian yang baru karena struktur perekonomian yang ada selama ini telah membawa kepada ketidak-adilan dan tidak memihak kepada sebagai besar rakyat dan atau pribumi. Menurut Hatta 
I-Economic Vol. 4. No 2. Desember 2018

Maqashid Koperasi Syariah .... Nurhadi

lembaga strategis dan menjadi "senjata persekutuan bagi si lemah untuk mempertahankan hidupnya". 66

Dalam Islam, koperasi termasuk kategori Syirkah/Syarikah. Syirkah menurut bahasa berarti al-ikhthilath yang artinya adalah campur atau percampuran. ${ }^{67}$ Dapat pula diartikan sebagai persekutuan dua atau lebih, sehingga masing-masing sulit dibedakan, misalnya persekutuan hak milik atau perserikatan usaha. ${ }^{68}$ Sedangkan menurut Wahbah az Zuhaili syirkah menurut bahasa adalah bercampurnya suatu harta dengan harta yang lain sehingga keduanya tidak bisa dibedakan lagi. ${ }^{69}$ Secara terminology ada beberapa definisi yang dikemukakan oleh Ulama' Fiqih, diantaranya adalah pendapat Sayyid Sabiq: Akad antara dua orang berserikat pada pokok harta (modal) dan keuntungan; ${ }^{70}$ Hasbi Ash-Shiddieqie: Akad yang berlaku antara dua orang atau lebih untuk ta'awun dalam bekerja pada suatu usaha dan membagi keuntungannya. ${ }^{71}$

Menurut Dimyauddin Djuwaini koperasi (musyarakah) adalah akad kerjasama antara dua pihak atau lebih untuk suatu usaha tertentu di mana masing-masing pihak memberikan kontribusi dana (atau kompetensi, expertise) dengan kesepakatan bahwa keuntungan dan risiko akan ditanggung bersama sesuai dengan kesepakatan. ${ }^{72}$ Seperti halnya mudharabah, musyrakah adalah akad kerjsama atau usaha patungan antara dua/lebih pemilik modal atau keahlian untuk melaksanakan suatau jenis usaha yang halal atau produktif. Bedanya dengan mudharabah adalah dalam hal pembagian untung-rugi dan keterlibatan peserta dalam usaha yang sedang dikerjakan. ${ }^{73}$

Adapaun syirkah menurut Kompilasi Hukum Ekonomi Syariah Pasal 20 (3) adalah kerjasama antara dua orang atau lebih dalam hal permodalan, keterampilan, atau kepercayaan dalam usaha tertentu dengan pembagian keuntungan berdasarkan nisbah yang disepakati oleh pihak-pihak yang berserikat. ${ }^{74}$

struktur perekonomian Indonesai di masa itu terdiri dari tiga golongan ekonomi yang tersusun bertingkat, yaitu: “...golongan atas ialah bangsa Belanda...Lapis ekonomi kedua yang menjadi perantara dan hubungan dengan masyarakat Indonesia berada kira-kira 90\% di tangan orang Cina dan orang Asing lainnya. Orang Indonesia yang dapat dimasukkanb ke dalam lapis kedua ini paling banyak mengisi $10 \%$ dari lapis itu... Lapis ketiga ialah perekonomian yang segala kecil; pertanian kecil, pertukangan kecil, perdagangan kecil dan lain-lain, itulah daerah ekonomi bangsa Indonesia. Pun pekerja segala kecil, kuli, buruh kecil dan pegawai kecil diambil dari dalam masyarakat Indonesia ini". Lihat: Anwar Abbas, Bung Hatta dan Ekonomi Islam, (Jakarta: Kompas, 2010), hlm. 163-165; lihat Zainil Ghulam, Implementasi Maqashid Syariah, hlm. 100-101

${ }^{66}$ Mohhamad Hatta, Beberapa Fasal Ekonomi; Djalan Ke Ekonomi dan Pembangunan, (Djakarta, Dinas Penerbitan Balai Pustaka, Tjetakan keenam, 1960), hlm. 120.

${ }^{67}$ Hendi Suhendi, Fiqh Muamalah, (Jakarta: PT. Raja Grafindo Persada, 2012), hlm.125.

${ }^{68}$ Ghufron A. Mas'adi, Fiqh Muamalah Kontekstual, (Jakarta: PT Raja Grafindo Persada, 2012), hlm. 191.

${ }^{69}$ Wahbah al-Zuhaili, Fiqh Islam, terj.Abdul Hayyie al-Kattani, (Jakarta: Gema Insani, 2011), hlm. 441.

${ }^{70}$ Sayid Tsabiq, Figh al-Sunnah (Lebanon: Dar al-Fikri, t.th), hlm. 294

${ }^{71}$ Hasbi Ash-Shiddieqie, Pengantar Fiqh Muamalah, (Jakarta: Bulan Bintang, 2004), hlm. 89.

${ }^{72}$ Nasrun Haroen, Fiqh Muamalah, (Jakarta: PT Gaya Media Pratama, 2007), hlm. 166.

${ }^{73}$ Dimayuddin Djuwaini, Fiqh Muamalat, (Yogyakarta: Pustaka Pelajar, 2010), hlm. 207-208.; lihat Wahbah al-Zuhaili, al-Fiqh al-Islamiy wa Adillatuhu, juz IV, (Damaskus: Dar al-Fikr, 1989), hlm. 792-793; lihat Zainil Ghulam, Implementasi Maqashid Syariah, hlm. 101

${ }^{74}$ Tim Redaksi, Kompilasi Hukum Ekonomi Syariah,(Bandung: Fokusmedia, 2008), hlm. 14 
I-Economic Vol. 4. No 2. Desember 2018

Maqashid Koperasi Syariah .... Nurhadi

Dari beerapa defenisi diatas dapat dismipulkan bahwa syirkah adalah kerja sama antara dua orang atau lebih dalam berusaha yang keuntungan dan kerugiannya ditanggung bersama. ${ }^{75}$

Landasan Syariah dibolehkannya akad syirkah berdasarkan dalil-dalil yang dapat dijumpai dalam al-Qur'an dan Hadits. ${ }^{76}$ Diantara dalil-dalinya al-Qur'an dalam surah Shad ayat 24 sebagaimana terdahulu, dari hadis riwayat Abu Daud juga telah disebutkan diatas. ${ }^{77}$ Juga ijma' ulama sebagaimana pendapat Ibnu Munzir yang dikutip Sayyid Tsabiq. ${ }^{78}$

Akad syirkah akan menjadi sah jika memenuhi rukun dan syaratnya. Hanya saja ulama' Fiqh berbeda pendapat dalam hal ini. Menurut ulama' Hanafiyah, rukun syirkah ada dua, yaitu ijab dan kabul sebab ijab kabul (akad) yang menentukan adanya syirkah. Adapun yang lain seperti dua orang atau pihak yang berakad dan harta berada di luar pembahasan akad seperti terdahulu dalam akad jual beli. ${ }^{79}$ Adapun syarat syirkah secara umum menurut Wahbah al-Zuhaili, sebagaimana dijelaskan Dimyauddin dan Zainil Ghulam, adalah sebagai berikut: ${ }^{80}$

a) Akad syirkah harus bisa menerima wukalah (perwakilan), setiap partner merupakan wakil dari yang lain, karena masing-masing mendapatkan izin dari pihak lain untuk menjalankan perannya. Dalam syirkah, setiap partner mendapatkan izin dari pihak lain untuk menjalankan transaksi bisnis, masing-masing partner merupakan wakil dari pihak lain. Sehingga, akad syirkah harus bisa diwakilkan (pekerjaan yang ada dalam syirkah harus bisa di-spread sehingga masing-masing pihak memiliki kontribusi, untuk itu, masing-masing partner harus mewakilkan pada pihak lain untuk menjalankan bagiannya).

b) Keuntungan bisa dikuantifikasikan, artinya masing-masing partner mendapatkan bagian yang jelas dari hasil keuntungan bisnis, bisa dalam bentuk nisbah atau prosentase, misalnya $20 \%$ untuk masing-masing partner.

c) Penentuan pembagian bagi hasil (keuntungan) tidak bisa disebutkan dalam jumlah nominal yang pasti (misal, Rp. 500.000.-, untuk masing-masing partner), karena hal ini bertentangan dengan konsep syirkah untuk berbagi dalam keuntungan dan risiko atas usaha yang dijalankan. ${ }^{81}$

Adapun macam-macam akad syirkah, secara sederhana dapat diklasifikasikan dalam dua jenis yakni syirkah al-amlak (syirkah kepemilikan) dan syirkah al- 'aqd (syirkah akad). ${ }^{82}$ syirkah al-amlak terjadi karena adanya wasiat, warisan atau perjanjian lain sehingga satu aset dimiliki oleh dua orang atau lebih. Sedangkan pembagian syirkah al-'aqd ada perbedaan pendapat dalam beberapa mazhab tentang pembagaiannya. ${ }^{83}$ Menurut Mazhab Hanabilah, terbagi menjadi lima yaitu: syirkah al'Inan, syirkah al-mufawadhah, syirkah al-abdan, syirkah alwujuh dan al-mudarabah. Sedangkan menurut mazhab Hanafiyah terbagi menjadi: syirkah al-

\footnotetext{
${ }^{75}$ Hendi Suhendi, Fiqh Muamalah, (Jakarta: PT. Raja Grafindo Persada. 2014), hlm. 125-127.

${ }^{76}$ Wahbah al-Zuhaili, al-Fiqh al-Islamiy wa Adillatuhu, juz IV, hlm. 793

${ }^{77}$ Zainil Ghulam, Implementasi Maqashid Syariah, hlm. 102

${ }^{78}$ Sayid Tsabiq, Fiqh al-Sunnah, hlm. 194.

${ }^{79}$ Ibid., hlm. 104

${ }^{80}$ Wahbah al-Zuhaili, al-Fiqh al-Islamiy wa Adillatuhu, juz IV, hlm. 432-433.

${ }^{81}$ Dimayuddin Djuwaini, Fiqh Muamalat, hlm. 208-209; lihat Zainil Ghulam, Implementasi Maqashid

${ }^{82}$ Sayid Tsabiq, Fiqh al-Sunnah, hlm. 196

${ }^{83}$ Zainil Ghulam, Implementasi Maqashid Syariah, hlm. 105
} Syariah, hlm. 104 
I-Economic Vol. 4. No 2. Desember 2018

Maqashid Koperasi Syariah .... Nurhadi

amwal, syirkah al-a'mal, syirkah al-wujuh dan setiap salah satu dari ketiganya terbagi adakalanya mufawadhah atau 'inan. ${ }^{84}$

Di sini penulis mengutip pendapat Mazhab Malikiyah dan Syafi'iyah yang membagi syirkah al-'aqd dalam: ${ }^{85}$

a) Syirkah al'Inan: adalah persekutuan antara dua orang dalam harta milik untuk berdagang secara bersama-sama, dan membagi laba atau kerugian bersama-sama. ${ }^{86}$

b) Syirkah al-Mufawadhah; adalah transaksi dua orang atau lebih untuk berserikat dengan syarat memiliki kesaman dalam jumlah modal, penentuan keuntungan, pengolahan, serta agama yang dianut. ${ }^{87}$

c) Syirkah al-Abdan: adalah persekutuan dua orang untuk menerima suatu pekerjaan yang dikerjakan secara bersama-sama. Kemudian keuntungan dibagi diantara keduanya dengan menetapkan persyaratan tertentu. Perkongsian ini terjadi, misalnya diantara dua orang penjahit, tukang besi dan lain-lain. ${ }^{88}$

d) Syirkah al-Wujuh: adalah bersekutunya dua pemimpin dalam pandangan masyarakat tanpa modal, untuk membeli barang secara tidak kontan dan akan menjualnya secara kontan, kemudian keuntungan yang diperoleh dibagi diantara mereka dengan syarat tertentu. ${ }^{89}$

Ketika rukun dan syarat akad syirkah terpenuhi maka akad tersebut menjadi sah. Namun sebaliknya, jika ada salah satu akad yang tidak terpenuhi maka otomatis akad tersebut akan batal. Prinsipnya, akad syirkah dapat terhenti jika salah satu mitra ada yang meninggal dunia, murtad atau mengalami gangguan jiwa. Bisa juga akad syirkah tidak dapat dilanjutkan jika ada mitra yang memutus kontrak perjanjian di tengah jalan karena kerugian atau suatu hal lainnya. Karena sebetulnya, masing-masing mitra mempunyai hak dasar untuk meneruskan akad syirkah ini atau memutuskannya. ${ }^{90}$

\section{Maqashid Muamalah Syirkah Koperasi}

Hikmah muamalah secara umum terealisasi dalam lima bentuk, yaitu: ${ }^{91}$

1) Mewujudkan ketundukan pada syariat Allah swt dibuktikan dengan nilai-nilai ibadah dalam kegiatan Muamalah Iqtishadiyah sesuai syariah, dengan melakukan syirkah koperasi secara syariah.

2) Melestarikan dan menghidupkan sunah Rasul saw dengan cara mengikuti sunnah Rasul saw dalam bermuamalah Iqtishadiyah sesuai tuntunan-Nya, dengan cara berinteraksi ekonomi secara syirkah sebagai bentuk tolong-menolong antar sesame.

3) Menjaga diri dari yang diharamkan Allah dan Rasul-Nya dan mengambil serta menikmati yang dihalalkan-Nya, dengan cara bersyirkah sesuai tuntunan al-Qur'an dan sunnah.

\footnotetext{
${ }^{84}$ Wahbah al-Zuhaili, al-Fiqh al-Islamiy wa Adillatuhu, juz IV, hlm. 794-795.

${ }^{85}$ Ibid.; lihat Zainil Ghulam, Implementasi Maqashid Syariah, hlm. 105

${ }^{86}$ Wahbah al-Zuhaili, al-Fiqh al-Islamiy wa Adillatuhu, juz IV, hlm. 444-445

${ }^{87}$ Rachmat Syafei, Fiqh Muamalah, (Bandung: Pustaka Setia, 2001), hlm. 186.; lihat Sayid Tsabiq, Fiqh Sunnah, terj. Abdurrohim Dan Masrukhin, (Jakatra, Cakrawala ublising, 2009), hlm. 407.

${ }^{88}$ Ibid., hlm. 190; lihat Nasrun Haroen, Fiqh Muamalah, hlm. 165-166.

${ }^{89}$ Ibid., hlm. 191; lihat Wahbah al-Zuhaili, al-Fiqh al-Islamiy wa Adillatuhu, juz IV, hlm. 447-448.

${ }^{90}$ Ibid., hlm. 191; lihat Zainil Ghulam, Implementasi Maqashid Syariah, hlm. 106

${ }^{91}$ Nurhadi, Konsep Hikmat al-Tasyri, hlm. 436
} 
I-Economic Vol. 4. No 2. Desember 2018

Maqashid Koperasi Syariah .... Nurhadi

4) Menumbuh kembangkan moral (ahklaq mulia dan budi pekerti luhur yaitu sifat amanah, bijaksana, jujur, kesucian hati/perasaan, dermawan dan sifat zuhud) dan materil (ketenangan dan keuntungan rezki halal berkah serta terjaga stabilitas ekonomi umat manusia).

5) Mewujudkan persaudaraan (ukhwah Islamiyah/tolong menolong) dan persatuan (menjauhkan dari iri dengki, saling menzalimi, permusuhan, perselisihan serta pertengkaran).

Maqashis (hikmah) pokoknya adalah hablum minallah (maqashid tauhidiyah wa ibadiyah) hablum minannas (maqashid khuluqiyah waqa'iyah). Maqashid (hikmah) induk dari seluruh جلب syariah adalah kemaslahatan hamba dunia akhirat, sesuai dengan kaedah Maqashidiyah menegakkan kemaslahatan dan menolakkan kemudratan. ${ }^{92}$

Manusia tidak dapat hidup sendirian, pasti membutuhkan orang lain dalam memenuhi kebutuhan. Ajaran Islam mengajarkan supaya kita menjalin kerjasama dengan siapapun terutama dalam bidang ekonomi dengan prinsip saling tolong menolong dan menguntungkan, tidak menipu dan merugikan. Tanpa kerjasama, maka kita sulit untuk memenuhi kebutuhan hidup. Syirkah pada hakikatnya adalah sebuah kerjasama yang saling menguntungkan dalam mengembangkan potensi yang dimiliki baik berupa harta atau pekerjaan. Oleh karena itu, Islam menganjurkan umatnya untuk bekerjasama kepada siapa saja dengan tetap memegang prinsip sebagaimana tersebut diatas. Maka maqashid (hikmah) yang dapat kita ambil dari syirkah yaitu adanya tolong menolong, saling bantu membantu dalam kebaikan, menjauhi sifat egoisme, menumbuhkan saling percaya, menyadari kelemahan dan kekurangan, dan menimbulkan keberkahan dalam usaha jika tidak berkhianat. ${ }^{93}$

Menurut Nurhadi sebagaimana dikutip dalam kitab hikamt al-Tasyri' yang dikarang oleh Al-Jurjawi,beliau tidak menyebutkan maqashid syirkah secara tersendiri, tapi beliau membaginya dalam tiga kategori syirkah, yaitu: 1). Syirkah Innan. 2). Syirkah Shanai'. 3). Syirkah Wujuh. Oleh karena itu, pada bagian pertama penulis akan menjelaskan hikmah syirkah secara umum, diikuti dengan hikmah dari tiga macam syirkah tersebut. ${ }^{94}$ Menurut AlJurjawi dalam kitabnya hikmat al-Tasyri' wa falsafatuhu, syarikat atau syirkah terbagi kepada tiga macam, yaitu: maqashid (hikmah) Syarikat Inan (Biro Jasa Perjalanan), maqashid (hikmah) Syarikat Shana'i (Kerjasama Dibidang Industri) dan maqashid (hikmah) Syirkah Wujuh (Biro Penerima Pesanan). Adapun hikmah-hikmah dari ketiga syirkah tersebut adalah:

1) Maqashid (hikmah) Syarikat Inan (Biro Jasa Perjalanan) Mengembangkan Harta. Inan dalam kitab Bada'i disebutkan bahwa kalimat "Inan" diambil dari asal kata "anni" yang diartikan dengan menampakkan. Dinamakan demikian karena aktivitasnya hanya akan dilakukan sesuai dengan keinginan dua atau salah satu dari kedunya, atau berdasarkan persamaan modal atau modal salah satunya lebih besar daripada yang lain. Sebgian mengatakan "inan" adalah orang yang sibuk mengendalikan tali kekang kudanya dengan menggunakan salah satu tangannya saja. Biro ini dikatakan Inan karena hanya mencakup sebagian modal, harta yang lain digunakan bebas sesuai dengan kemauan kedua orang yang menggabungkan modal tersebut atau karena masing-masing dari keduanya membagi penggunaan modal secara bersama-sama. Kerjasama ini mempunyai hikmah yaitu kemaslahatan umat di setiap zaman yang berada.

\footnotetext{
${ }^{92} \mathrm{Ibid}$.

${ }^{93}$ Abdul Rahman Ghazaly, Ghufron Ihsan, Sapiudin Shidiq, Fiqh Muamalat, (Jakarta: Kencana, 2010), Edisi 1, Cet. Ke-1, hlm. 135.

${ }^{94}$.Ayat-ayat tentang syirkah adalah surah shad ayat 24. Lihat Dwi Suwiknyo, Kompilasi Tafsir Ayat-Ayat Ekonomi Islam, (Yogyakarta: Pustaka Pelajar, 2010), hlm. 189-192; Nurhadi, Konsep Hikmat al-Tasyri, hlm. 374
} 
I-Economic Vol. 4. No 2. Desember 2018

Maqashid Koperasi Syariah .... Nurhadi

Karena pada dasarnya mereka perlu mengembangkan modal dan kerja sama ini termasuk salah satu cara mengembangkan modal. ${ }^{95}$

2) Maqashid (hikmah) Syarikat Shana'i (Kerjasama Dibidang Industri)/Keterampilan. Hikmah kerjasama dalam perindustrian adalah bahwa dua orang pemodal suatu indsutri, jika keduanya telah sepakat untuk membangun sebuah perusahaan, maka hal itu akan membawa manfaat yang sangat besar bagi keduanya yang di antaranya adalah menghasilkan rezeki, dengan demikian industri bisa semakin besar dan dibuka cabang-cabang di daerah lain untuk mebuka lapangan pekerjaan dan membuka pintu rezeki untuk orang lain. Kerjasama industri juga mempunyai hikmah untuk mengembangkan kreasi dalam ilmu tegnologi, baik kedokteran maupun penelitian serta pabrik-pabrik. Hikmahnya juga terhindarnya dari saling menzolimi antar sesama, dan mengajarkan sifat amanah yang merupakan sikap dan sifat yang sangat mulia. ${ }^{96}$

3) Maqashid (hikmah) Syirkah Wujuh (Biro Penerima Pesanan). Hikmah kerjasama ini adalah membantu mengentasakan kemiskinan, juga menjanjikan pahala bagi yang kaya kepada yang miskin. Orang yang memiliki harta akan mengangkat orang yang lemah dari segi harta dari kehinaan, kekurangan dan profesi meminta-minta dan akan mendekatkan diri kepada Allah swt dan menjadi orang-orang yang beruntung. Biro ini juga dinamakan biro jasa penerimaan karena ia menjual kredit atas anjuran dari orang lain. ${ }^{97}$

Salah satu bentuk syirkah adalah koperasi. Maqashid Koperasi syariah adalah berjamaah dalam usaha atau kegiatan usaha yg berbasis komunitas. Filosofinya sendiri adalah kemandirian, mulai dari diri kemudian menjadi kemandirian kelompok (umat). Ataupun sebaliknya, kemandirian kelompok yang mendorong kemandirian individu didalamnya. Sumber daya yang terhimpun dari anggota adalah jalan bagi pencapaian kedaulatan ekonomi, sehingga berkoperasi sebetulnya adalah strategi usaha jangka panjang yang mengamankan kepentingan bisnis setiap anggota dari persaingan yang tidak sehat. Berkoperasi adalah membangun benteng dari upaya-upaya menghancurkan dan menjajah para pemodal besar dan pemilik usaha yang lebih mapan.

Maqashid Koperasi syariah pada tataran religi adalah pemusatan kekuatan dalam menghalau bentuk-bentuk muamalah yang terlarang dan ideologi yang menyesatkan. Riba itu primadona dunia usaha, keberadaannya adalah turunan langsung dari paham kapitalis yg mendudukkan uang diatas segalanya. Hanya solidaritas yg mampu menahan gempuran ekspansi usaha bisnis kapitalis, solidaritas yg melembaga itu namanya koperasi.

Menurut penulis maqashid syirkah koperasi mengandung maqashid (hikmah) yang sangat besar, baik bagi pelakunya maupun bagi masyarakat luas, diantaranya sebagai berikut :

1) Terkumpulnya modal dengan jumlah yang besar, sehingga dapat digunakan untuk mengadakan pekerjaan-pekerjaan besar pula.

${ }^{95}$ Ali Ahmad al-Jurjawi, Hikmat al-Tasyri' wa Falsafatuhu, (Bairut Lebanon : Daar al-Fikr, 1994 M/ 1414 H), Juz II, hlm. 96. Lihat juga Ali Ahmad al-Jurjawi, Hikmat al-Tasyri' wa Falsafatuhu, diterjemahkan oleh Faisal Sakeh, dkk., Indahnya Syariát Islam, (Jakarta, Gema Insani, 2006 ), hlm. 447-448. Lihat Al-Jurjawi, Ali Ahmad. 1996. Hikmat al-Tasyri' wa Falsafatuhu, Terjemahan Nabhani Idris, Lc, Rahasia hukum Islam (Jakarta: PT. Raja Grafindo), hlm. 312-313.

${ }^{96}$.Ali Ahmad al-Jurjawi, Hikmat al-Tasyri, Juz II, hlm. 97. Lihat juga terj. Paisal Saleh Dkk, Indahnya, hlm. 448-449. Lihat juga terj. Nahbani Idris, Indahnya, hlm. 313.

${ }^{97}$.Ali Ahmad al-Jurjawi, Hikmat al-Tasyri', Juz II, hlm.97-98. Lihat juga terj. Paisal Saleh dkk, Indahnya, hlm. 449-450. Lihat juga terj. Nahbani Idris, Indahnya, hlm. 313-114.; Nurhadi, Konsep Hikmat al-Tasyri, hlm. 376 
I-Economic Vol. 4. No 2. Desember 2018

Maqashid Koperasi Syariah .... Nurhadi

2) Dapat memperlancar laju ekonomi makro.

3) Terciptanya lapangan pekerjaan yang lebih luas dan memadai.

4) Terjalinya rasa persaudaraan diantara sesama pemegang modal dan mitra kerja yang lain.

5) Pemikiran untuk memajukan perusahaan menjadi lebih banyak karena berasal dari banyak orang pula.

6) Transaksi perserikatan secara umum bisa berahir atau batal dengan beberapa syarat :

1. Salah satu pihak mengundurkan diri

2. Wafatnya salah satu pihak

3. Salah satu pihak menderita penyakit gila yang sulit disembuhkan

4. Salah satu pihak murtad (keluar dari Islam) dan melarikan diri kenegri yang berperang dengan negri muslim, karena orang seperti ini dianggap telah wafat.

\section{Kesimpulan}

Maqashid Koperasi syariah adalah berjamaah dalam usaha atau kegiatan usaha yg berbasis komunitas. Filosofinya sendiri adalah kemandirian, mulai dari diri kemudian menjadi kemandirian kelompok (umat). Ataupun sebaliknya, kemandirian kelompok yang mendorong kemandirian individu didalamnya. Sumber daya yang terhimpun dari anggota adalah jalan bagi pencapaian kedaulatan ekonomi, sehingga berkoperasi sebetulnya adalah strategi usaha jangka panjang yang mengamankan kepentingan bisnis setiap anggota dari persaingan yang tidak sehat. Berkoperasi adalah membangun benteng dari upaya-upaya menghancurkan dan menjajah para pemodal besar dan pemilik usaha yang lebih mapan.

Maqashid Koperasi syariah dalam tataran religi adalah pemusatan kekuatan dalam menghalau bentuk-bentuk muamalah yang terlarang dan ideologi yang menyesatkan. Riba itu primadona dunia usaha, keberadaannya adalah turunan langsung dari paham kapitalis yg mendudukkan uang diatas segalanya. Hanya solidaritas yg mampu menahan gempuran ekspansi usaha bisnis kapitalis, solidaritas yg melembaga itu namanya koperasi.

Maqashid syirkah koperasi syariah mengandung enam maqashid, sebagai berikut :

1) Terkumpulnya modal dengan jumlah yang besar, sehingga dapat digunakan untuk mengadakan pekerjaan-pekerjaan besar pula.

2) Dapat memperlancar laju ekonomi makro.

3) Terciptanya lapangan pekerjaan yang lebih luas dan memadai.

4) Terjalinya rasa persaudaraan diantara sesama pemegang modal dan mitra kerja yang lain.

5) Pemikiran untuk memajukan perusahaan menjadi lebih banyak karena berasal dari banyak orang pula.

6) Transaksi perserikatan secara umum bisa berahir atau batal

\section{Daftar Pustaka}

Abdul Rahman Ghazaly, Ghufron Ihsan, Sapiudin Shidiq, Fiqh Muamalat, (Jakarta: Kencana, 2010), Edisi 1, Cet. Ke-1

Abu Ishak al-Syathibi, al-Muwafaqat fi Usul Syariah, (Dar al-Kutub al-Ilmiyah, Beirut-Libanon)

Ahmad al-Mursi Husain Jauhar, Maqashid Syariah, (Amzah, Jakarta 2009). Lihat juga M. Supri Assyagily,

Aliran-Aliran

Maqashid

al-Syariah, 
I-Economic Vol. 4. No 2. Desember 2018

Maqashid Koperasi Syariah .... Nurhadi

http://orientalisstudies.blogspot.co.id/2014/10/aliran-aliran-maqasid-al-Syariah.html,dldiakses Tanggal 24 Januari 2017 Jam $06.00 \mathrm{Wib}$.

Al-Hikmah, Koperasi dalam Islam, lihat dalam wibesite online alamat http://www.alhikmah.ac.id/koperasi-dalam-islam-2/.diakses tgl 26 agustus 2018.

Ali Ahmad al-Jurjawi, Hikmat al-Tasyri' wa Falsafatuhu, (Bairut Lebanon : Daar al-Fikr, 1994 M/ 1414 H), Juz II

Ali Ahmad Al-Jurjawi, Hikmat al-Tasyri' wa Falsafatuhu, Terjemahan Nabhani Idris, Lc, Rahasia hukum Islam (Jakarta: PT. Raja Grafindo, 1996)

Ali Ahmad al-Jurjawi, Hikmat al-Tasyri' wa Falsafatuhu,diterjemahkan oleh Faisal Sakeh, dkk., Indahnya Syariát Islam, (Jakarta, Gema Insani, 2006 )

Ali Imron Hasan, Aktualisasi Prinsip Prinsip Syariah Dalam Berkoperasi Di Pondok Pesantren, lihat dalam wibesite online alamat http://imronmangkang.blogspot.com/2013/10/aktualisasiprinsip-prinsip-syariah.html.diakses tgl 26 agustus 2018.

Al-Zahrah, Koperasi dalam Pandangan Islam, lihat dalam wibesite online alamat http://khamsatul.blogspot.com/2012/01/koperasi-dalam-pandangan-islam.html.diakses tgl 27 agustus 2018.

Amin Farih, Kemaslahatan dan Pembaharuan Hukum Islam, (Semarang : Walisongo Press, 2008)

Anwar Abbas, Bung Hatta dan Ekonomi Islam, (Jakarta: Kompas, 2010)

Dakwatuna, Prinsip Dasar Koperasi Syariah, artikel wibesitw online lihat dalam alamat sebagai https://www.dakwatuna.com/2009/08/08/3360/prinsip-dasar-koperasi-

syariah/\#axzz5PNbb2Ks1.diakses tgl 25 agustus 2018

Departemen Agama RI, Al-Qur'an dan Terjemahannya (Semarang: Toha Putra, 2005)

Dimayuddin Djuwaini, Fiqh Muamalat, (Yogyakarta: Pustaka Pelajar, 2010)

Dinnul Alfian Akbar, Inflasi, Gross Domesctic Product (Gdp), Capital Adequacy Ratio (Car), dan Finance To Deposit Ratio (Fdr) Terhadap Non Performing Financing (Npf) Pada Bank Umum Syariah di Indonesia (Jurnal I-Economic Vol. 2. No.2 Desember 2016)

Dwi Suwiknyo, Kompilasi Tafsir Ayat-Ayat Ekonomi Islam, (Yogyakarta: Pustaka Pelajar, 2010)

Ghufron A. Mas'adi, Fiqh Muamalah Kontekstual, (Jakarta: PT Raja Grafindo Persada, 2012)

Hasbi Ash-Shiddieqie, Pengantar Fiqh Muamalah, (Jakarta: Bulan Bintang, 2004)

Hendi Suhendi, Fiqh Muamalah, (Jakarta: PT. Raja Grafindo Persada, 2012)

Hendi Suhendi, Fiqh Muamalah, (Jakarta: PT. Raja Grafindo Persada. 2014)

Ilmam Aziz, Pemasaran Koperasi Syariah, lihat dalam wibesite online alamat https://aziz27.wordpress.com/2009/06/29/pemasaran-koperasi-syariah/.diakses tgl 27 agustus 2018.

Imam Abu Daud, Sunan Abu Daud, dalam Kitab : Jual beli, pada Bab : Jual beli persekutuan, No. Hadist : 2936

Imam Ahmad, Musnad Ahmad bin Hambal, dalam Kitab : Sisa Musnad sahabat yang banyak meriwayatkan hadits, pada Bab : Musnad Abu Hurairah Radliyallahu 'anhu, No. Hadist : 7118

Julius R. Latumaerissa, Bank dan Lembaga Keuangan Lain, (Jakarta: Salemba Empat, 2013)

Kosmi Karawang, Sejarah Koperasi Syariah, lihat dalam wibesite online alamat http://www.kosmipro.com/2018/02/posting-4.html.diakses tgl 26 agustus 2018.

Lemiyana, Pengaruh Produk Terhadap Keputusan Nasabah Perbankan Syariah (Studi Kasus Perbankan Syariah di Kota Palembang), (Jurnal I-Finance Vol. 4. No. 1. Juni 2018) 
I-Economic Vol. 4. No 2. Desember 2018

Maqashid Koperasi Syariah .... Nurhadi

M. Supri Assyagily, Aliran-Aliran Maqashid al-Syariah, lihat dalam artikel online wibesite http://orientalisstudies.blogspot.co.id/2014/10/aliran-aliran-maqasid-al-Syariah.html,dldiakses Tanggal 24 Januari 2017 Jam 06.00 Wib.

M. Supri Assyagily, Aliran-Aliran Maqashid al-Syariah, lihat dalam artikel onlline wibesite http://orientalisstudies.blogspot.co.id/2014/10/aliran-aliran-maqasid-al-Syariah.html,dldiakses Tanggal 24 Januari 2017 Jam $06.00 \mathrm{Wib}$.

Maman Suherman, Aliran Ushul Fiqh Dan Maqashid Syari'ah, Jurnal Demo : Purchase From Www.A-PDF.Com To Remove The Watermark

Masbodik, Koperasi dalam Kacamata Syariah, lihat dalam wibesite online alaat https://masbodik.wordpress.com/2008/08/25/koperasi-dalam-kacamata-syariah/.diakses tgl 26 agustus 2018.

Mohhamad Hatta, Beberapa Fasal Ekonomi; Djalan Ke Ekonomi dan Pembangunan, (Djakarta, Dinas Penerbitan Balai Pustaka, Tjetakan keenam, 1960)

Muftifiandi, Peran Pembiayaan Produk Ar-Rum Bagi Umkm pada PT. Pegadaian (Persero) Cabang Syariah Simpang Patal Palembang (Jurnal I-Finance Vol. 1. No. 1. Juli 2015)

Muhammad Hatta, Membangun Koperasi dan Koperasi Membangun (Jakarta: Inti Idayu Press, 1987)

Nasrun Haroen, Fiqh Muamalah, (Jakarta: PT Gaya Media Pratama, 2007)

Nurhadi, Konsep Hikmat al-Tasyri sebagai asas Ekonomi dan Keuangan Bisnis Islam dalam Kitab Hikmat al-Tasyri wa falsafathu Karya Ali Ahmad l-Jurjawi (1866-1961 M), Disertasi UIN Suska Riau, 2018)

Oni Syahroni dan Adiwarmab Karim, Maqashid Bisnis dan Keuangan Islam (Jakarta: Rajawali Pers, 2016)

Rachmat Syafei, Fiqh Muamalah, (Bandung: Pustaka Setia, 2001)]

Ropi Marlina, Yola Yunisa Pratami, Koperasi Syariah sebagai Solusi Penerapan Akad Syirkah yang Sah (Jurnal Amwaluna, Vol. 1 No. 2, Juli, 2017)

Rustam Effendi, dkk, Konsep Koperasi Bung Hatta Dalam Perspektif Ekonomi Syariah, (Jurnal AlHikmah Vol. 15 No. 1 April 20180)

Sayid Tsabiq, Fiqh al-Sunnah (Lebanon: Dar al-Fikri, t.th)

Sayid Tsabiq, Fiqh Sunnah, terj. Abdurrohim Dan Masrukhin, (Jakatra, Cakrawala ublising, 2009)

Tim Redaksi, Kompilasi Hukum Ekonomi Syariah,(Bandung: Fokusmedia, 2008)

Wahbah al-Zuhaili, al-Fiqh al-Islamiy wa Adillatuhu, juz IV, (Damaskus: Dar al-Fikr, 1989),

Wahbah al-Zuhaili, Fiqh Islam, terj. Abdul Hayyie al-Kattani, (Jakarta: Gema Insani, 2011)

Warkum Sumitro, Asas-Asas Perbankan Islam dan Lembaga- Lembaga Terkait, (Jakarta: PT. Raja Grafindo Persada, 2002)

Zainil Ghulam, Implementasi Maqashid Syariah dalam Koperasi Syariah (Jurnal Iqtishoduna Vol. 7

No. 1 April 2016) 